\title{
Shell weight as an independent variable in relation to cadmium content of molluscs
}

\author{
Helmut Fischer
}

Institut für Meereskunde an der Universität Kiel, Düsternbrooker Weg 20, D-2300 Kiel 1, Federal Republic of Germany

\begin{abstract}
Shell weight of molluscs is introduced as alternative parameter for biological monitoring of heavy metals. Variability of metal concentration due to variations in soft-body weight can be eliminated by relating metal body burden to shell weight. A reformed 'Mussel Watch' concept is outlined. Detailed investigation of $\mathrm{Cd}$ in mussels exemplifies advantages of the new approach. The relation of $\mathrm{Cd}$ body burden to shell weight is constant in relation to environmental Cd concentration. In contrast, conventional $\mathrm{Cd}$ concentration values of soft tissues, in general, are related to the physical condition of mussels. The dependency of condition and $\mathrm{Cd}$ concentration on individual size, tidal exposure, spawning, and nutrient supply is documented. Accumulation of $\mathrm{Cd}$ in soft tissues and formation of the calcareous shell are discussed in terms of influx of environmental ions and organismic immobilisation, together with their respective organic ligands.
\end{abstract}

\section{INTRODUCTION}

Molluscs are known to concentrate numerous toxic substances to a considerable degree over environmental levels. This property makes them a potential hazard for the human consumer since commercially exploited stocks normally grow in inshore waters and may be contaminated. On the other hand, the molluscan capacity to magnify and integrate aquatic pollutants is considered to play a key role in monitoring environmental quality: substantial methodological efforts and risks of contamination in sampling water containing only traces of pollutants might be circumvented via analysing molluscs instead. Thus bivalves have been proposed as indicator organisms for heavy metals (e.g. Schulz-Baldes, 1973; Darracott and Watling, 1975; Phillips, 1976a, b). Meanwhile the term 'Mussel Watch' (Goldberg, 1975) has entered the environmentalists' terminology as a standard phrase, and first synopses on monitoring by means of biological content indicators have been published (Phillips, 1977, 1980; Wright, 1978).

As a convention, analytical data are expressed as the concentration of heavy metals in the soft body of molluscs on a dry weight or wet weight basis. High concentrations of metals were found in samples from heavily contaminated estuaries or harbour areas (e.g.
Butterworth et al., 1972; Phillips, 1976b; Theede et al., 1979 ) or in the close vicinity of known point sources (e.g. Popham et al., 1980; Jensen et al., 1981). But since metal concentrations in molluscs from uncontaminated water masses vary widely, only differences of more than one order of magnitude have been considered as being significant (Goldberg et al., 1978). Thus the indicator ability of molluscs for heavy metals in the environment appears to have been restricted to extremely polluted water masses.

Many authors stress that local differences in body weight (or 'metabolic and physiological status', Davies and Pirie, 1980) and seasonal weight fluctuations are responsible for much of the variability of heavy-metal concentrations in molluscs (e.g. Phillips, 1976a; Cossa et al., 1979; Orren et al., 1980; Zaroogian, 1980). The total content of heavy metals in the soft body of molluscs, however, varies considerably less than the tissue concentration (Zaroogian, 1980), or may even remain almost constant over the year (Phillips, 1976a). Consequently, there are 2 principal ways for improving the use of molluscs as indicators of environmental heavy metals: (1) reducing weight variability by eliminating or correcting for the influence of causative environmental or organismic factors; (2) using a less variable parameter that relates to heavy metal body burden better. 
This study introduces the shell weight of conchifereous molluscs as an alternative variable in relation to the heavy metal content of the soft body.

The investigations were restricted to cadmium. This heavy metal is of low toxicity to marine biota (review: Mohlenberg and Jensen, 1980), but it may become hazardous to man as a result of his intake of seafood, especially when the burden from other sources is already high (Umweltbundesamt, 1981). Mytilus edulis, the common blue mussel, is accepted worldwide as a sentinel organism for heavy metals. This species was investigated in detail with regard to variability due to individual size, position in the water column, and season (compare Phillips, 1976a), and with regard to its indicator ability for environmental Cd.

\section{MATERIAL AND METHODS}

\section{Sampling}

Molluscs were collected in the Western Baltic Sea at locations known to be more (Kiel Fjord) or less polluted (Eckernförde Bight) according to preceding investigations (water data 1977/78: Kremling et al., 1979; cadmium in mussels 1975/76: Theede et al., 1979). The mean salinity in this area is approximately $15 \% \mathrm{~S}$; water temperature ranges from about $0^{\circ} \mathrm{C}$ (winter) to over $17^{\circ} \mathrm{C}$ (summer); there is virtually no tide. Other samples were taken from the German Wadden Sea NE of the island of Sylt ( $30 \% \mathrm{~S}$; mean tidal range $1.71 \mathrm{~m})$.

No attempt was made to minimize variability in the sampling procedures. In contrast, utmost heterogeneity of individuals was chosen as a major test criterion for the applicability of shell weight as an independent variable throughout the study.

The mussels were collected and placed in clean sea water to allow elimination of gut contents; they were then killed by wet heat at $60^{\circ} \mathrm{C}$. Following water drainage the bivalves were deep-freeze stored. In contrast, gastropods were extracted from their shells immediately; after freezing and thawing their digestive glands would otherwise often remain in the shell.

\section{Analyses}

For cadmium analyses 40 to 50 specimens of each sample covering the whole size range collected were thawed and shucked. Soft bodies were freeze-dried individually, oven-dried for $2 \mathrm{~d}$ at $60^{\circ} \mathrm{C}$, weighed, and ground to powder. Approximately 20-mg subsamples of each individual were wet-digested with $0.2 \mathrm{ml}$ of a 1:1 mixture of concentrated nitric acid and perchloric acid, gently heated to near dryness, and dissolved in de-ionised water. Samples were analysed for Cd by flameless AAS.

Shells were dried overnight at $60^{\circ} \mathrm{C}$, weighed, and the length (gastropods: height) determined. Shells (of Mytilus edulis only), selected at random, were dissolved in diluted hydrochloric acid (Sturesson, 1978) or acetic acid, and the organic components analysed for $\mathrm{Cd}$ in the same way as the soft tissues. The $\mathrm{HCl}$ dissolved calcareous components of the shells were analysed by straightforward injection into the AAS. In this case the $\mathrm{Cd}$-references were prepared from saturated $\mathrm{CaCl}_{2}$-solutions.

\section{Calculations}

All calculations refer to dry weight of soft tissues and shells. Treatment of data follows the outlines given by Boyden $(1974,1977)$. He found that the plotting of element content against soft-body weight on double logarithmic scales generally produces a straight line relationship:

$$
\log \text { metal }=\log a+b \log \text { weight }
$$

If this holds for the metal over the whole size range of specimens, and if the slope $b$ remains constant in different samples of a given species, then comparisons could be based solely on the intercept $\log a$ or its linear equivalent $a$ by reference to a standard weight of 1 unit (as $b \log 1=0)$.

The nutritional state of mussels is expressed as the condition index (Gabbott and Walker, 1971), which is the soft body dry weight fraction of the total dry weight:

$$
\mathrm{CI}=\frac{\text { dry weight of soft tissues }}{\text { total dry weight }} \times 100(\%)
$$

Throughout this study, comparisons of slopes and intercepts are based on the $95 \%$ confidence intervals of means. Real differences are evident when the confidence intervals do not overlap (Sachs, 1978).

\section{RESULTS}

\section{Multispecies survey}

Samples of different conchifereous species were collected at locations distant from industrialised areas (Fig. 1; Locations 1, 2 and 4). Sufficient numbers of cockles Cardium edule and clams Mya arenaria could be found at more sheltered places only (Locations 5 and 6). 
Fig. 1. Sampling sites in SWKiel Bight. Exposed (1 to 4), sheltered ( 5 to 7 ) and polluted locations ( 8 to 10 )

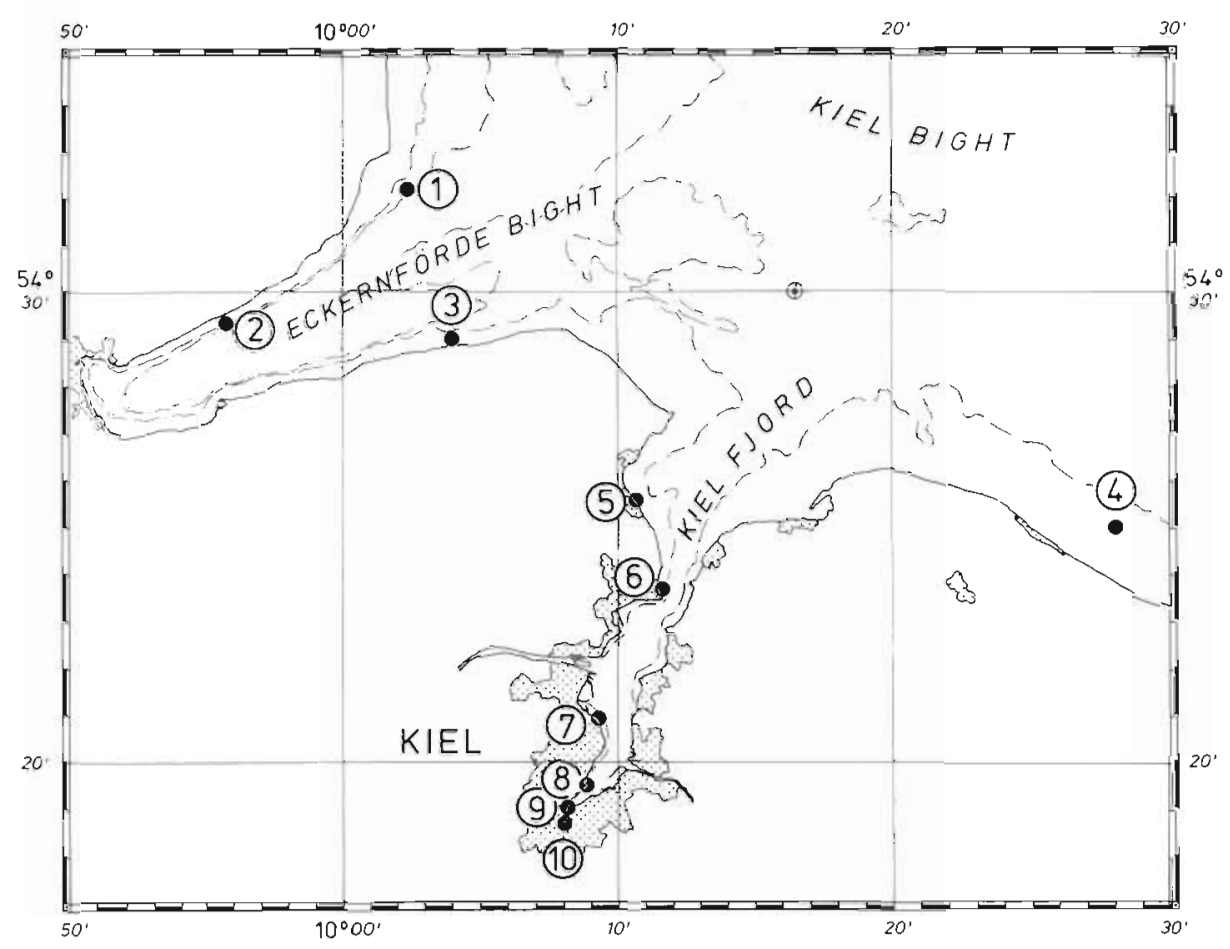

As described by Boyden $(1974,1977)$, power functions

$$
\mathrm{Cd}=a \times \mathrm{wt}^{b}, \text { hence } \log \mathrm{Cd}=\log a+b \times \log \mathrm{wt}
$$

were suitable to describe the relation between cadmium content $(\mathrm{Cd}, \mu \mathrm{g})$ and soft-body dry weight (meat wt, g) or the dry weight of the shells (shell wt, g). Linear or exponential functions relating $\mathrm{Cd}$ and weight did not fit the data as well (Table 1).

In Astarte borealis it was not possible to compute a common $\mathrm{Cd} /$ meat-wt regression over the whole size range, since older and younger specimens, which may represent year classes, exhibited different slopes. The same trend was observed in a Mytilus edulis sample, but there were too few older specimens to permit a separate calculation. In Cardium edule there were slightly higher Cd concentrations in one of the samples, but the $95 \%$-confidence intervals of means overlapped.

When the weight of the calcareous shell was used as the independent variable instead of the soft body dry weight, the $\mathrm{Cd} /$ shell-wt regression was continuous over the whole size range in Astarte borealis. In contrast, the 2 samples of Cardium edule differed markedly with respect to their intercepts (Fig. 2, right).

In most species analysed the accumulation rate of $\mathrm{Cd}$ in the soft tissues tends to proceed slightly faster than the formation of the calcareous shell. This is expressed by the fact that the slope $b$ of the $\mathrm{Cd} /$ shell-wt regression is slightly greater than 1 . The intercept ln a may express a species-dependent ratio between the rates of both processes when comparing different species from

Table 1. Cadmium body burden $(\mu \mathrm{g})$ of several mollusc species in relation to soft-body dry weight (meat wt, $g$ ) and shell weight (shell wt, g). Sampling: autumn 1980; sites see Fig. 1

\begin{tabular}{|c|c|c|c|c|c|c|c|c|c|c|}
\hline \multirow[t]{2}{*}{ Species } & \multirow[t]{2}{*}{ Site } & \multirow[t]{2}{*}{$\mathrm{n}$} & \multicolumn{4}{|c|}{$\begin{array}{c}C d=a \times \text { meat } w^{b} \\
\ln C d=\ln a+b \times \ln \text { meat } w t\end{array}$} & \multicolumn{4}{|c|}{$\begin{array}{c}C d=a \times \text { shell } w t^{b} \\
\ln C d=\ln a+b \times \ln \text { shell } w t\end{array}$} \\
\hline & & & $\mathrm{a}$ & $\ln a$ & b & r & $\mathrm{a}$ & $\ln a$ & $\mathrm{~b}$ & r \\
\hline \multirow[t]{2}{*}{ Astarte borealis } & 1 & 21 & 2.4893 & 0.9120 & 0.9061 & 0.9641 & \multirow{2}{*}{0.1392} & \multirow{2}{*}{-1.9715} & \multirow{2}{*}{1.1721} & \multirow{2}{*}{0.9743} \\
\hline & & 37 & 13.1195 & 2.5741 & 1.4248 & 0.8919 & & & & \\
\hline \multirow[t]{2}{*}{ Cardium edule } & 5 & 31 & 0.7333 & -0.3102 & 0.7532 & 0.8736 & 0.1033 & -2.2697 & 1.1248 & 0.8825 \\
\hline & 6 & 28 & 0.5527 & -0.5929 & 0.7181 & 0.8986 & 0.0654 & -2.7271 & 1.0610 & 0.9192 \\
\hline Mya arenaria & 5 & 17 & 0.3240 & -1.1270 & 0.9802 & 0.9628 & 0.0843 & -2.4731 & 0.8922 & 0.9835 \\
\hline Macoma balthica & 4 & 106 & 0.2196 & -1.5160 & 1.0275 & 0.8867 & 0.0342 & -3.3745 & 0.9489 & 0.8997 \\
\hline Mytilus edulis & 4 & 105 & 1.5971 & 0.4682 & 1.0290 & 0.9786 & 0.2420 & -1.4189 & 1.0916 & 0.9913 \\
\hline Littorina littorea & 3 & 52 & 2.6993 & 0.9930 & 1.0474 & 0.9781 & 0.2416 & -1.4203 & 1.3135 & 0.9834 \\
\hline
\end{tabular}




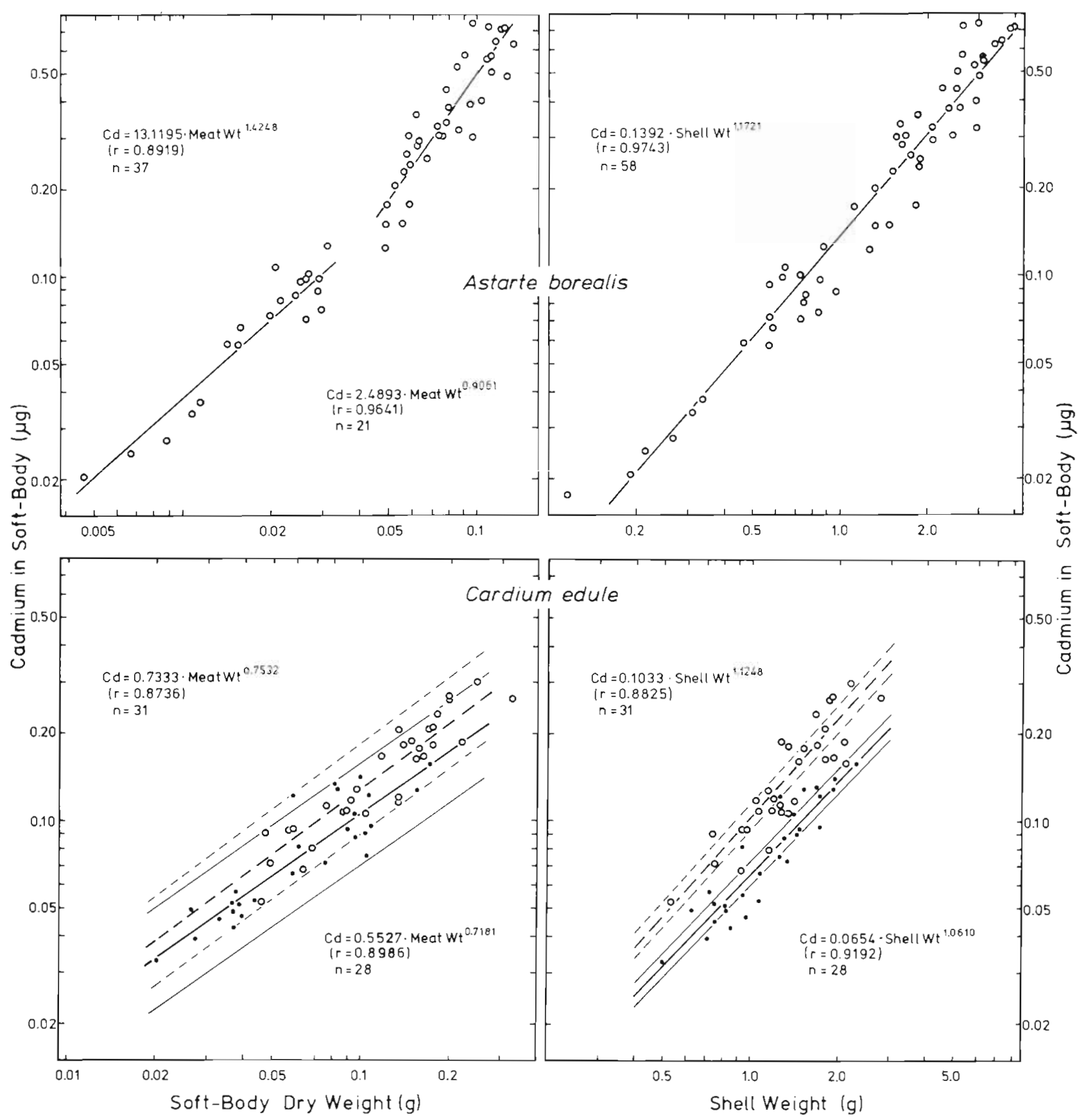

Fig. 2. Astarte borealis (Location 1) and Cardium edule (Locations 5 and 6, autumn 1980). Relating the Cd body burden to shell weight (right) instead of to meat weight (left) produces steady regression lines (A. borealis) and clear-cut differences ( $C$. edule, with $95 \%$ confidence intervals of means). $r$ : linear regressions

the same site, or may indicate different availability of cadmium at different sites as in the two samples of Cardium edule. $a$ is the amount of cadmium $(\mu \mathrm{g})$ in a specimen with a shell weight of $1 \mathrm{~g}$.

These inital findings suggest that reference to shell weight can be advantageous for biological monitoring of $\mathrm{Cd}$. This is verified in the following detailed investigations of Mytilus edulis.

\section{Investigations of Mytilus edulis}

Cd balance of soft body and shells

No cadmium could be detected in the dissolved calcareous components or in the organic remains of shells. The detection limit was $0.05 \mu \mathrm{g} \mathrm{Cd} \mathrm{g}^{-1}$ shell (without chemical extraction). A meat-wt/shell-wt 
ratio of approximately 0.14 and a Cd concentration of approximately $2 \mu \mathrm{g} \times \mathrm{g}^{-1}$ meat are further basic data for a balance calculation:
A shell of $1 \mathrm{~g}$ contains at most

The corresponding soft tissues of $0.14 \mathrm{~g}$ contain

The entire mussels contains at most
$0.05 \mu \mathrm{g} \mathrm{Cd}$

$0.28 \mu \mathrm{g} \mathrm{Cd}$

$0.33 \mu \mathrm{g} \mathrm{Cd}$
Hence, $85 \%$ or more of the Cd in Kiel Bight mussels is located in the soft parts.

Throughout this study, the $\mathrm{Cd}$ body burden refers to the amount accumulated in the soft tissues, disregarding minor quantities that may be present in the shells.

\section{Individual size}

\section{Size and condition}

Mussels were dredged from $7 \mathrm{~m}$ depth in Eckernförde Bight (Location 3, autumn 1980). The size of individuals analysed ranged from 13 to $100 \mathrm{~mm}$ shell length, or 0.01 to $40 \mathrm{~g}$ shell weight.

Subsamples of small, medium-sized, and large individuals were distinguished with regard to size frequency, shell characteristics, and condition index (C I). Shell weights of approximately 5 and $20 \mathrm{~g}$ were appropriate to delimit the subsamples from each other.
When Cd was related to weight of soft parts, the subsamples differed markedly (Fig. 3, left). In s m a ll mussels, the $\mathrm{Cd}$ concentration of soft parts decreased with size, i.e. the slope $b$ of the $\mathrm{Cd} /$ meat-wt regression was significantly ( $\mathrm{p} \leq .01)$ smaller than 1 (Fig. 3, left). In mussels of medium size, the Cd concentration increased with size: $b$ exceeded 1 ( $p \leq .0001$ ). In very large specimens, Cd concentrations were highest, but the accumulated amount was not correlated with the weight of the soft body. The calculated $\mathrm{Cd} /$ meat-wt regression line was almost parallel with the in softbody dry-wt axis, the slope being not significantly different from zero.

When the amount of $\mathrm{Cd}$ in the soft body was related to the weight of the shells, the $\mathrm{Cd} /$ shell-wt regressions of the subsamples were virtually identical. A common regression line could be calculated that covered the whole size range of individuals (Fig. 3, right).

Plotting analytical data against shell weight as independent variable (Fig. 4) shows: (1) In the subsample of small individuals, soft-body weight increases faster than shell weight. In medium-size mussels, the trend is reversed. In very large mussels there is no more net growth of the soft body, but the shell weight continues to increase (Fig. 4a, solid lines). (2) C I and ratio shell weight to soft-body dry weight are derived from basic data. Their relation can be characterised roughly as being inversely proportional (Fig. 4a, b, broken lines).

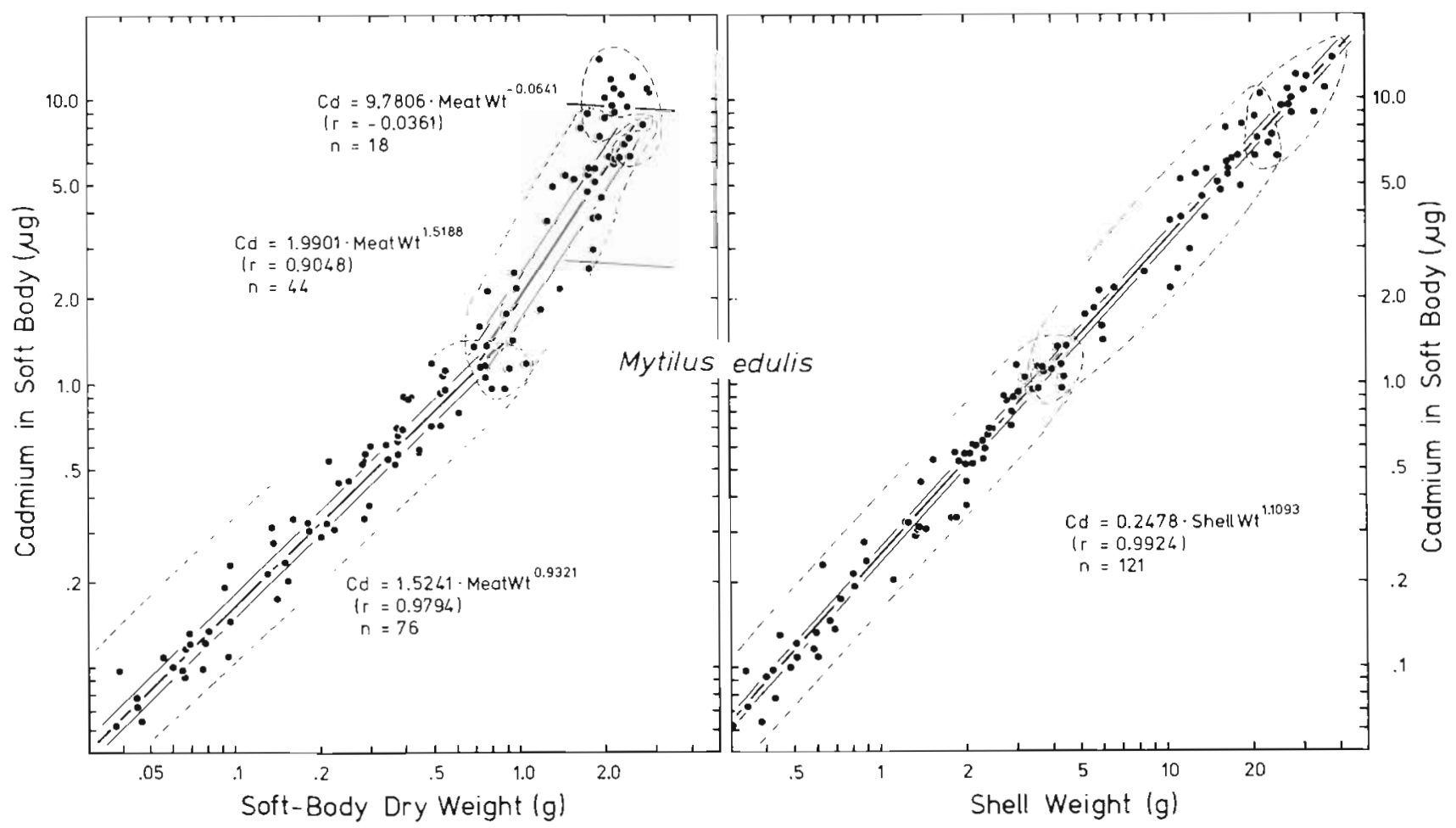

Fig. 3. Mytilus edulis (Location 3, autumn 1980). Size-dependent differences of Cd/meat-wt regressions (left) and common $\mathrm{Cd} /$ shell-wt regression (right) with $95 \%$ confidence intervals of means. r: linear regression lines 
Mytilus edulis
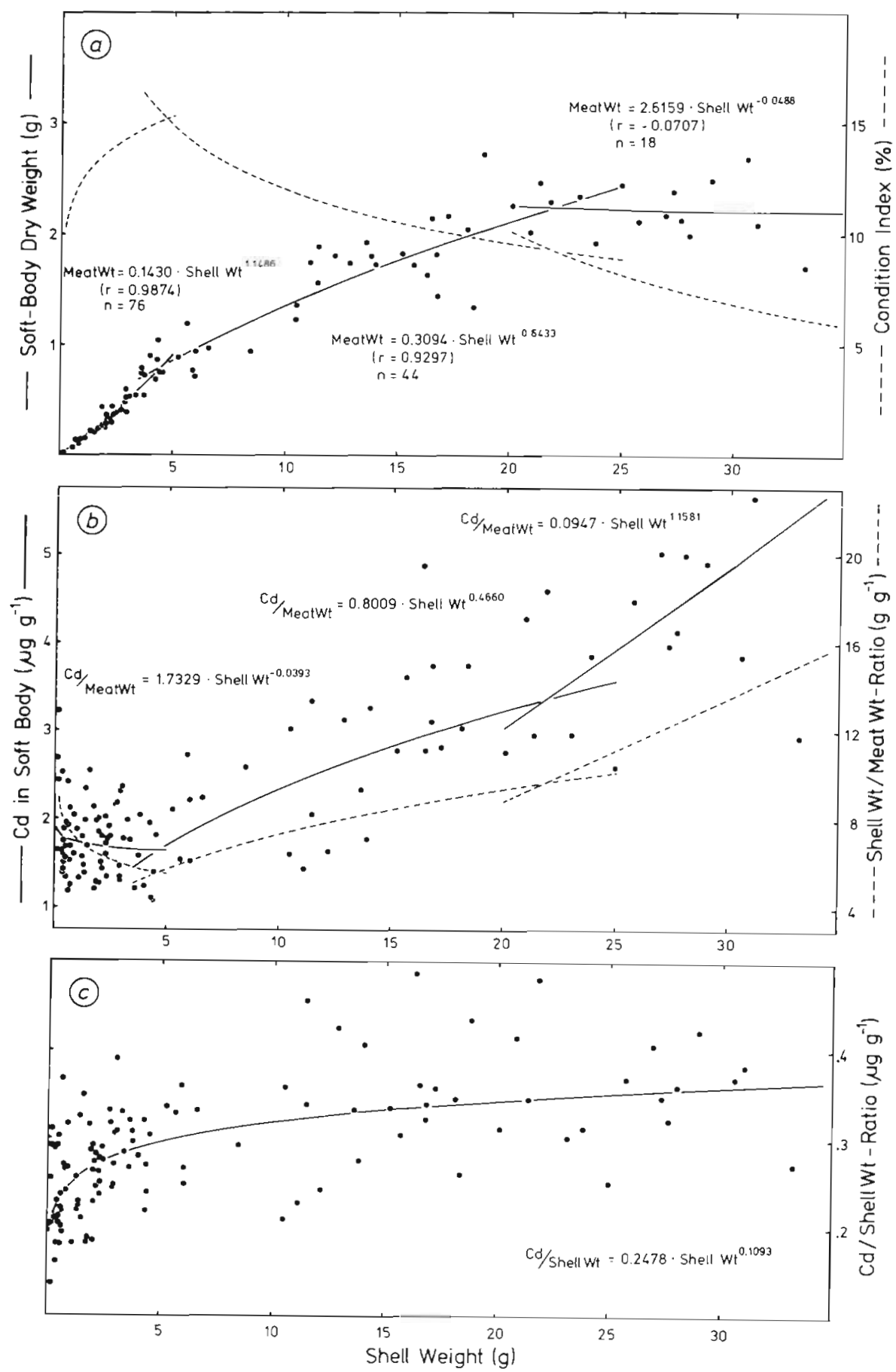

Fig. 4. Mytilus edulis (Location 3, autumn 1980). (a) Juvenile, adult, and senescent mussels exhibit different growth rates of soft body relative to shells (solid lines) which produces size-specific trends of the CI (broken lines). (b) Cd concentration of soft body (solid lines) reflects the ratio of shell weight to softbody weight (broken lines). (c) Relation of Cd body burden and shell weight is steady over the whole size range

(3) Development of Cd concentration reflects changes with size of the ratio between shell weight and softbody dry weight: A high $\mathrm{Cd}$ concentration is found in mussels with a high relative shell weight, i.e. with a low C I. Greater Cd concentrations are found in very small and very large mussels (Fig. 4b). (4) Large specimens contain relatively more $\mathrm{Cd}$ than small ones, but the relation between $\mathrm{Cd}$ in soft body and weight of calcareous shell is steady over the whole size range (Fig. 4c).

\section{Evaluation}

The above interrelationships between shell weight, soft body, and $\mathrm{Cd}$ exemplify some general findings throughout this study. In small (juvenile) mussels, 
higher ratios of shell weight to soft-body weight have been observed repeatedly - a phenomenon that may be modified by external variables in its extent, but not in its general pattern. In medium-size (adult) mussels the net increase of the soft body declines with size. In the largest (senescent) mussels, seasonal weight increase equals losses by spawning and seasonal starvation (Jörgensen, 1976), and net losses of soft body weight may occur prior to death. Shell growth in terms of annual length increments is known to diminish with age, but formation of the calcareous shells continues: heavy (thick) shells indicate greater age of mussels (Havinga, 1929; Seed, 1968).

The inverse development of $\mathrm{Cd}$ concentration and C I within all size subsamples intensifies doubts as to the usefulness of soft-body weight as an appropriate independent variable for biological monitoring. It can be predicted that any variable influencing the C I, or nutritional state of mussels, will modify the Cd concentration in the opposite direction.

The $\mathrm{Cd}$ concentration of Eckernförde Bight water has been shown to remain almost constant with time (Kremling et al., 1979) under normal hydrographical conditions. The size range of individuals analysed covers ages from 0.5 to more than $6 \mathrm{yr}$. Constancy of environmental cadmium is reflected in a common $\mathrm{Cd} /$ shell-wt regression for all size subsamples.

Position in water column

\section{High turbulence, no tide}

Mussels were collected in Dec. 1980 in Eckernförde Bight (Location 3) from depths of $7 \mathrm{~m}$ (coarse sand and gravel) and $1 \mathrm{~m}$ (wooden structure).

$\mathrm{Cd}$ concentrations were the same in mussels of comparable size in the 2 subsamples, and there were no differences in nutritional state in terms of the C I. Sizedependent differences were similar to those described above.

The Cd/shell-wt regressions of the surface and the bottom subsamples were virtually identical and steady over the whole size range. Slope and intercept were the same as in the preceding sample from the same location (Fig. 3, right).

\section{High turbulence, tidal waters}

Mussels were collected in Aug. 1981 from a remote tidal flat $\mathrm{NE}$ of the island of Sylt $\left(\varphi=55^{\circ} 05,4^{\prime} \mathrm{N}\right.$; $\left.\lambda=8^{\circ} 16,1^{\prime} \mathrm{E}\right)$ and dredged from a nearby submerged mussel bed $\left(\varphi=55^{\circ} 02,2^{\prime} \mathrm{N} ; \lambda=8^{\circ} 17,2^{\prime} \mathrm{E}\right)$.

When relating $\mathrm{Cd}$ body burden to soft-body dry
Table 2. Mytilus edulis from the German Wadden Sea, summer 1981. Effect of tidal exposure on condition, Cd concentration, and $\mathrm{Cd} / \mathrm{shell}-\mathrm{wt}$ interrelationship. $95 \%$ confidence interval of mean values

\begin{tabular}{|c|c|}
\hline Submerged bank, $\mathrm{n}=52$ & Tidal mud flat, $\mathrm{n}=31$ \\
\hline $\mathrm{CI}=15.3 \%$ & $\mathrm{CI}=8.6 \%$ \\
\hline $\mathrm{Cd}=\frac{.3716}{\frac{.3315}{.2957}} \times$ meat $w \mathrm{t} .9378$ & $\mathrm{Cd}=\frac{.8068}{.4795} \times$ meat $\mathrm{wt}^{9745}$ \\
\hline $\mathrm{Cd}=\frac{.0719}{.0663} \times$ shell $\mathrm{wt}^{1.1077}$ & $\mathrm{Cd}=\frac{.0685}{.0527} \times$ shell $\mathrm{wt}^{1.3054}$ \\
\hline
\end{tabular}

weight, the tidal subsample contained ca. twice the $\mathrm{Cd}$ concentration of submerged mussels (Table 2).

The CI of the tidally submerged mussels was roughly half that of the subtidal mussels (Table 2).

No differences were found between the Cd/shell-wt relationship of the tidal and the subtidal sample (Table 2).

\section{Low turbulence, no tide}

Mussels were collected in Kiel Fjord (Location 7 , Dec. 1980) from the bottom (6 $\mathrm{m}$ depth) and from wooden piles ( $2 \mathrm{~m}$ depth and surface). A soft bottom at this site indicated low turbulence in the water. Apart from a minor salinity gradient with depth of $+0.2 \% \mathrm{~S}$ $\mathrm{m}^{-1}$ (Kändler, 1960) the water column was virtually unstratified with regard to hydrographical parameters.

Mussels from different depths exhibited different $\mathrm{Cd} /$ meat-wt regressions both with regard to intercepts and slopes (Fig. 5, left). In small specimens below $0.1 \mathrm{~g}$ meat weight, the $95 \%$ confidence intervals overlapped. Highest mean concentrations of approximately $5 \mu \mathrm{g} \mathrm{Cd} \mathrm{g}{ }^{-1}$ meat were found in the bottom subsample. Mussels from $2 \mathrm{~m}$ depth and from sporadic groups near mean water level exhibited lower Cd concentrations (1.5 and $0.9 \mu \mathrm{g} \mathrm{g}^{-1}$ meat). High Cd concentrations were also detected in specimens from $2 \mathrm{~m}$ depth located in the centre of dense clusters (double circles).

The C I declined with increasing water depth. Mean values were 22,15 , and $5 \%$ in the surface, $2 \mathrm{~m}$, and bottom subsamples. Individuals overgrown by others were also of lower nutritional state (C I = $9 \%$ ).

When the $\mathrm{Cd}$ body burden was related to shell weight as an alternative parameter, there were virtually no differences between the 3 subsamples in the slopes and intercepts of the $\mathrm{Cd} /$ shell-wt regressions (Fig. 5, right). The mussels from the interior of clumps (double circles) fitted the common pattern as well. 


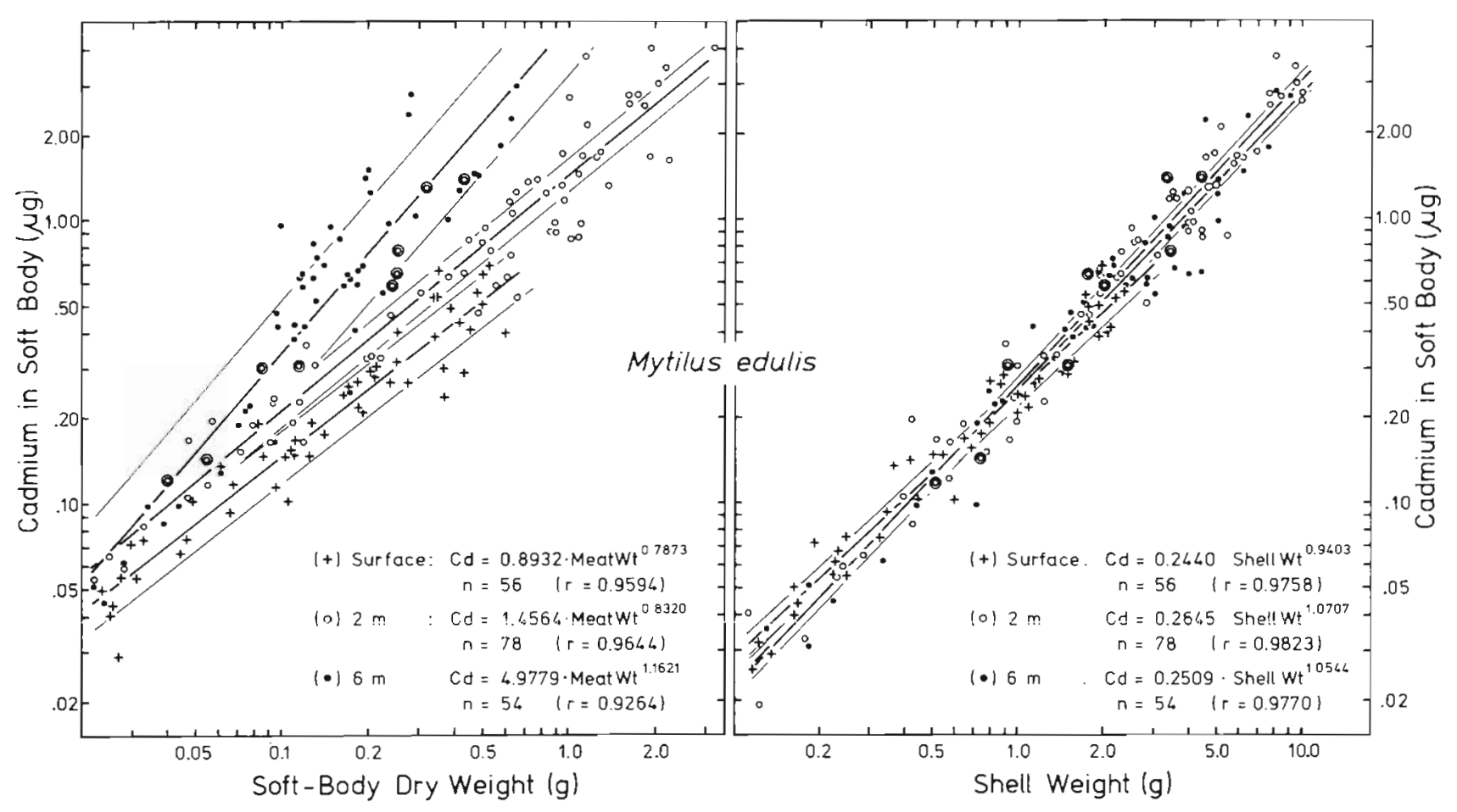

Fig. 5. Mytilus edulis (Location 7, winter 1980). Depth-dependent differences of the Cd/meat-wt regression (left), but close conformity of $\mathrm{Cd} /$ shell-wt regressions (right). $95 \%$ confidence intervals of means; $r$ : linear regressions
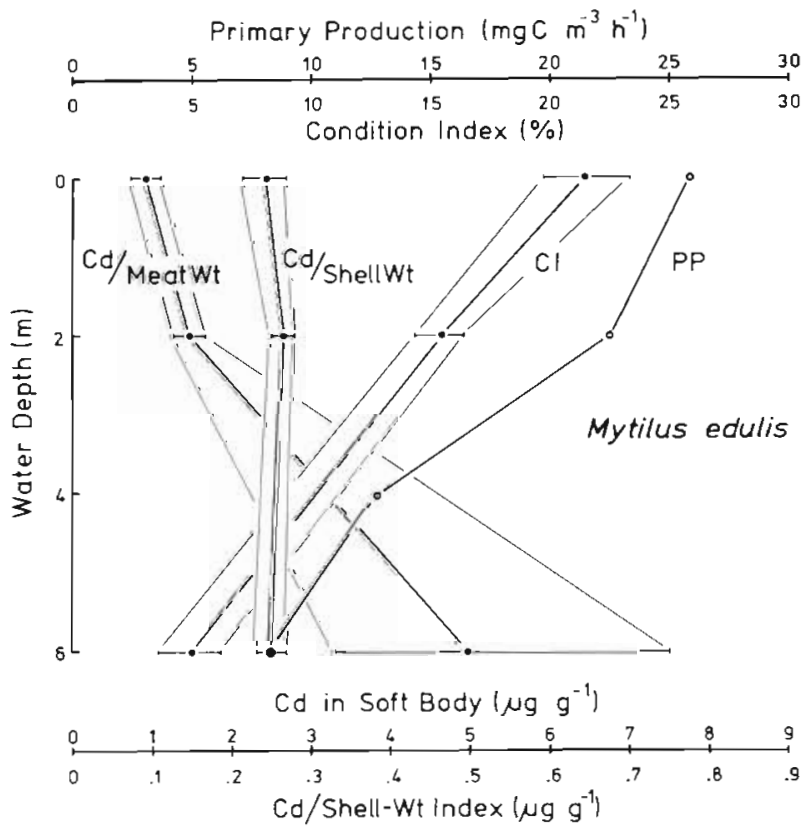

Fig. 6. Mytilus edulis (Location 7, December 1980), and primary production of inner Kiel Fjord (means of monthly determinations 1974-1975; original data: Probst, 1977). Depthdependent differences of $\mathrm{Cd}$ concentrations reflect the decrease of the CI with depth which is a result of lower nutrient supply. The $\mathrm{Cd} /$ shell-wt ratio indicates uniform $\mathrm{Cd}$ availability with depth (95\% confidence intervals of means are given)

\section{Evaluation}

High turbulence in Eckernförde Bight, tidal mixing in the Wadden Sea, and virtually no hydrographical stratification above 7 to $8 \mathrm{~m}$ in Kiel Fjord water are indicative of uniform availability of $\mathrm{Cd}$ with depth. In all 3 cases the congruence of the depth subsamples $\mathrm{Cd} /$ shell-wt regressions is in accordance with the assumption that there is no depth gradient in $\mathrm{Cd}$ availability.

The observed differences of $\mathrm{Cd} /$ meat-wt regression can be attributed to differences in the condition of the mussels with depth, as described by the CI. However, the reasons for this relationship vary. In $\mathrm{tidal}$ waters, populations from sites above the low water mark are characterised by slow growth and heavy shells (Baird and Drinnan, 1957) though, when submerged, food supply will be the same due to tidal mixing. In mussels from $\mathrm{c}$ a $\mathrm{lm}$ waters, a low $\mathrm{Cl}$ in bottom samples reflects limited food supply which is a result of reduced primary production with depth (Kiel Fjord data: Probst, 1977) interacting with low turbulence (Fig. 6). In either case a low C I and a high Cdconcentration of the soft parts are the resulting characteristics while the $\mathrm{Cd} / \mathrm{shell}$-wt relationship remains unchanged. This holds as well for those individuals that live in a high productivity water layer but are 
Table 3. Mytilus edulis from inner Kiel Fjord, June 1982. Effect of spawning on condition index, Cd concentration, and Cd/shellwt ratio. $95 \%$ confidence intervals of means

\begin{tabular}{|c|c|c|c|c|c|c|c|}
\hline Shell weight & Criterion & \multicolumn{3}{|c|}{ Controls, $\mathrm{n}=32$} & \multicolumn{3}{|c|}{ Spawned, $\mathrm{n}=35$} \\
\hline $.8 \mathrm{~g}$ & $\begin{array}{c}\mathrm{CI} \\
\mathrm{Cd} / \text { meat wt } \\
\mathrm{Cd} / \text { shell wt }\end{array}$ & $\begin{array}{r}26.9 \\
.90 \\
.34\end{array}$ & $\frac{\frac{27.9}{1.01}}{\frac{.38}{1}}$ & $\begin{array}{r}29.0 \\
1.13 \\
.43\end{array}$ & $\begin{array}{r}13.4 \\
2.13 \\
.32\end{array}$ & $\frac{\frac{14.6}{2.50}}{\underline{42}}$ & $\begin{array}{r}16.0 \\
2.94 \\
.55\end{array}$ \\
\hline $5.0 \mathrm{~g}$ & $\begin{array}{c}\mathrm{C} \mathrm{I} \\
\mathrm{Cd} / \text { meat wt } \\
\mathrm{Cd} / \text { shell wt }\end{array}$ & $\begin{array}{r}23.4 \\
1.03 \\
.34\end{array}$ & $\frac{\frac{24.3}{1.16}}{.39}$ & $\begin{array}{r}25.3 \\
1.30 \\
.43\end{array}$ & $\begin{array}{r}16.2 \\
1.68 \\
.32\end{array}$ & $\frac{\frac{17.6}{1.98}}{\underline{.42}}$ & $\begin{array}{r}19.2 \\
2.32 \\
.56\end{array}$ \\
\hline
\end{tabular}

overgrown by competitors and thus cut off from nutrient supply.

\section{Seasonal variability}

\section{Spawning}

Mussels in a ready-to-spawn state were dredged from Eckernförde Bight (Location 2, Feb. 1981) and scraped from piles in Kiel Harbour (Locations 7 to 8 , June 1982). Vigorous spawning could be induced by combined mechanical and temperature stimuli (Loosanoff and Davies, 1963). Mussels smaller than $0.8 \mathrm{~g}$ shell weight $\simeq 0.35 \mathrm{~g}$ dry weight (Kiel Harbour) did not spawn.

Larger mussels of more than $5 \mathrm{~g}$ shell weight lost 35 to $40 \%$ of their initial soft body dry weight (Table 3 ). In small specimens of 0.8 to $1.0 \mathrm{~g}$ shell weight the loss was ca. $55 \%$. In either case the decrease of the condition index was accompanied by a corresponding increase in the mean $\mathrm{Cd}$ concentration of the remaining soft tissues.

The relation between $\mathrm{Cd}$ in soft-body and shell weight was not significantly affected by spawning, but data were scattered more than in the controls. Table 3 gives a balance calculation for the sample from Kiel Harbour. The different extent of weight loss in small and large specimens, the cadmium body burden remaining unchanged, results in a reduced slope and an increased intercept of the spawned mussels $\mathrm{Cd} /$ meat-wt regression. The observation of small mussels having released a higher percentage of body weight as gonadal products may be due to uncompleted spawning of the large individuals (findings and calculations of Bayne and Worrall (1980) show the opposite).

\section{Changing growth conditions}

Since autumn 1980, mussels have been dredged at 3-mo intervals from submersed beds in Eckernförde Bight (Locations 3 and 1, upshore). A similar sampling programme has been carried out since the summer of 1981 in the Wadden Sea $\left(\varphi=55^{\circ} 05,2^{\prime} \mathrm{N}_{i} \lambda=\right.$ $\left.8^{\circ} 17,2^{\prime} \mathrm{E}\right)$. Calculations for mussels of $10 \mathrm{~g}$ shell weight are illustrated in Fig. 7.

\section{Mytilus edulis}

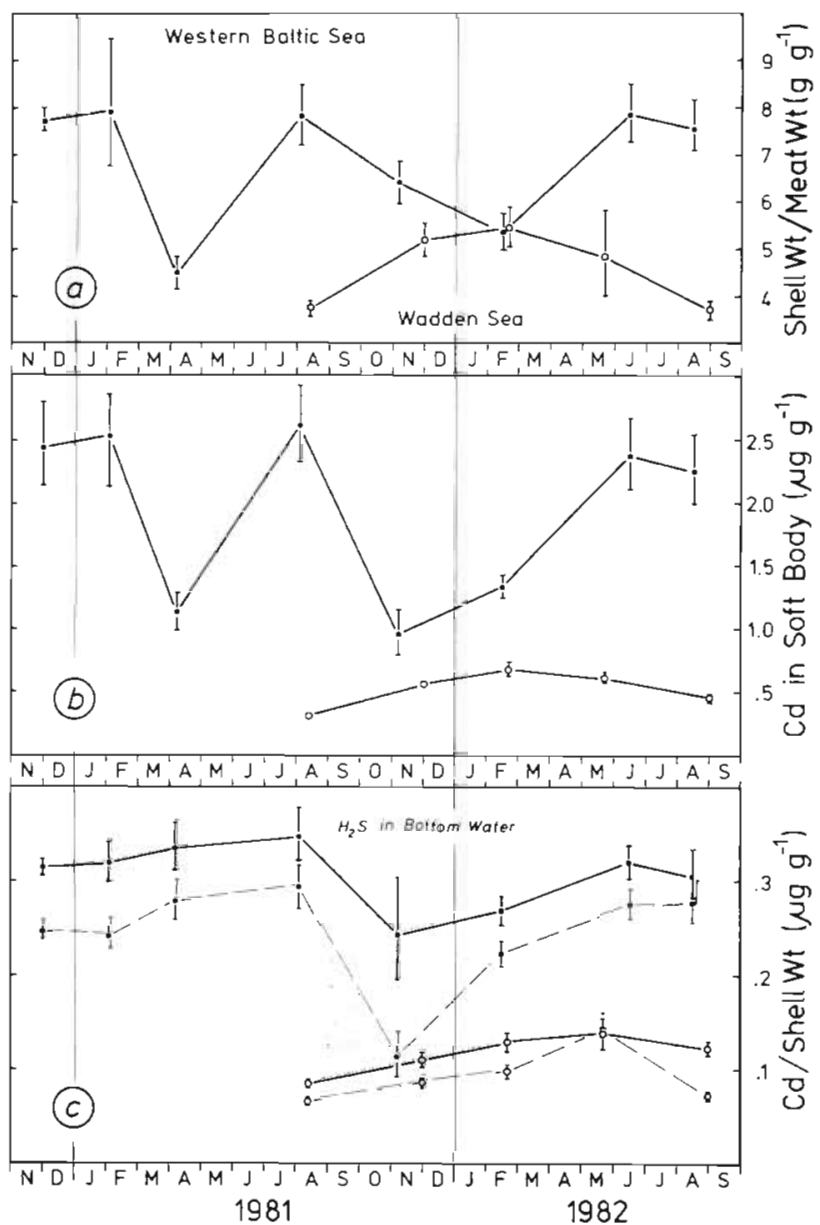

Fig. 7. Mytilus edulis (Western Baltic Sea and Wadden Sea; individual shell weight $10 \mathrm{~g}$, broken line: $1 \mathrm{~g}$ ). (a) Western Baltic Sea and Wadden Sea mussels show a temporal offset in seasonal nutritional state. (b) Seasonal differences of physical condition are reflected in Cd concentration. (c) Cd/shellwt ratio reflects $\mathrm{Cd}$ availability. $95 \%$ confidence intervals of means 
The weight ratio of shell to soft body differed with season in both populations (Fig. 7a). In the Western Baltic Sea, minimum values, i.e. maximum condition indices, were found in late winter and spring, followed by a sharp increase towards maximum relative shell weight in early summer. Maximum and minimum shell weight of Wadden Sea mussels were found in late winter and late summer, respectively, and the average relative shell weight was lower than in mussels from the Western Baltic Sea.

In general, the $\mathrm{Cd}$ concentration of the soft body varied in the same direction as the weight ratio of shell to soft body (Fig. 7b). In Baltic mussels, however, there was a disproportionate decrease of $\mathrm{Cd}$ concentration in autumn 1981, and from November 1981 to February 1982 the concentrations increased though the relative shell weight decreased. Mean Cd concentrations of Western Baltic mussels were approximately 4 times higher than in Wadden Sea mussels.

Relating the accumulated $\mathrm{Cd}$ to shell weight produced an almost constant ratio in the Baltic samples from autumn 1980 until summer 1981. Reasonable lower values were recorded in autumn 1981. After a slow increase the initial values were reached again in the summer of 1982 .

The Cd/shell-wt ratio of Wadden Sea mussels was roughly one third of the Baltic value, and seasonal differences were apparent (Fig. $7 \mathrm{C}$ ).

The $\mathrm{Cd}$ /shell-wt ratio in small mussels of $1 \mathrm{~g}$ shell weight, i.e. the (transferred) intercept a of the $\mathrm{Cd} /$ shell-wt regression exhibited the same general pattern in both samples, but changes in small mussels were more pronounced and values were lower than in larger specimens.

\section{Evaluation}

Spawning and variable food supply are the main reasons for seasonal weight fluctuations of the soft body.

For spawning, prior environmental influences including $\mathrm{Cd}$ are identical for both spawned mussels and controls. Weight losses correspond to increases in $\mathrm{Cd}$ concentration. The $\mathrm{Cd} /$ shell-wt regression remains unchanged; this shows that the $\mathrm{Cd}$ body burden is not influenced by spawning.

In seasonal studies, constancy of environmental variables - with time in this case - cannot be presumed, and the observed data on mussels need to be related to results on water parameters. In mussels from the Wadden Sea and from the Western Baltic Sea the Cd concentrations reflect gross changes of nutritional state throughout the years. The $C$ I of Wadden Sea mussels seems to be closely related to the annual cycle of irradiation, which determines primary production rates. The observed shift of the seasonal patterns in Western Baltic mussels can be attributed to specific hydrographical and biotic variables that modify the actual availability of phytoplankton (Review: Lenz, 1981).

The unexpected course of $\mathrm{Cd}$ concentration in Baltic mussels between autumn 1981 and spring 1982 corresponds to lower values of the $\mathrm{Cd} /$ shell-wt ratio. In the light of the results presented so far this has to be ascribed to lower $\mathrm{Cd}$ availability in the water, and there are data to support this conclusion:

(1) A general constancy of dissolved Cd in Eckernförde Bight throughout the year has been established by Kremling et al. (1979).

(2) In September 1981, the bottom water (below $20 \mathrm{~m}$ ) in large parts of the Western Baltic Sea was void of oxygen due to an unusual period of calm weather (Ehrhardt and Wenk, 1982). According to Kremling (1982), the Cd concentration of the water below the $\mathrm{O}_{2}$ ' $\mathrm{H}_{2} \mathrm{~S}$-interface must have drastically decreased due to the precipitation of cadmium sulfide.

(3) In October 1981 the meteorological situation changed, and the surface water was mixed with the (Cd-depleted) bottom water (Ehrhardt and Wenk, 1982). Lowered Cd availability in the surface water as a consequence is reflected in Iower $\mathrm{Cd} /$ shell-wt ratios in mussels.

For the Wadden Sea NE of Sylt, direct water data are available: Sperling (1982) reports minimum total and dissolved $\mathrm{Cd}$ in autumn and roughly double those concentrations from winter to early summer at this and several other Wadden Sea locations. The course of the $\mathrm{Cd} /$ shell-wt ratio of small mussels follows these changes. Larger specimens reflect an integrated overall state. Compared to summer 1981, the 1982 values in large mussels were higher, though the ratio in small mussels was the same. The reason for this can be found in the development of the mussel population: The largest individuals of the 1981 sample had shell weights of 5 to $6 \mathrm{~g}$, and the $\mathrm{Cd} /$ shell-wt ratio was extrapolated to $10 \mathrm{~g}$ shell weight. One year later, the largest mussels had grown to approximately $10 \mathrm{~g}$ shell weight. Their higher $\mathrm{Cd} / \mathrm{shell}$-wt ratio reflects one additional year of age with higher environmental cadmium from winter to spring 1982. The higher general

Table 4. Mytilus edulis. Slopes (with $95 \%$ confidence intervals) of $\mathrm{Cd} / \mathrm{shell}-\mathrm{wt}$ regressions of Western Baltic Sea and Wadden Sea mussels

\begin{tabular}{|lccccc|}
\hline \multicolumn{1}{c}{ Area } & Salinity & \multicolumn{3}{c}{$\begin{array}{c}95 \% \text { confidence } \\
\text { interval of } b\end{array}$} & $\mathrm{n}$ \\
\hline $\begin{array}{l}\text { Western Baltic } \\
\text { Wadden Sea }\end{array}$ & $15 \%$ & 1.05 & $\underline{1.08}$ & 1.11 & 7 \\
& $30 \%$ & 1.08 & $\underline{1.11}$ & 1.14 & 5 \\
\hline
\end{tabular}


level in large mussels corresponds to the slope $b$ of the $\mathrm{Cd} /$ shell-wt regressions exceeding 1 in both populations.

\section{Reformed 'Mussel Watch' concept}

Cadmium/shell-weight index

\section{Shell weight as independant variable}

All results obtained so far suggest that shell weight should replace the conventional soft-body (dry) weight for biological monitoring of $\mathrm{Cd}$. Additional evidence is gained from statistical elimination of the influence of one of the variables on the determination of the $\mathrm{Cd}$ body burden by the other (Sachs, 1978). In all cases studied there was a significant positive correlation ( $\mathrm{p} \leq .001$ ) between $\mathrm{Cd}$ and shell weight of Mytilus edulis when the influence of soft body dry weight was excluded. Cadmium and soft body dry weight a l on e were not correlated in the majority of cases. Therefore higher Cd amounts in mussels with larger soft body weights must be attributed to the concomitant increase of shell weight.

\section{Size normalisation}

Normalisation is necessary when samples cannot be compared directly because of differing individual sizes. As an undispensable prerequisite, the slopes of the samples' regression lines must be the same. It has been shown that this is not always the case when $\mathrm{Cd}$ is related to soft-body weight. Different slopes of the $\mathrm{Cd} /$ meat-wt regressions reflect unequal development of the $C$ I due to intrinsic or extrinsic variables. In contrast, slopes (and intercepts) of the $\mathrm{Cd}$ /shell-wt regressions are constant when environmental cadmium remains the same (Table 4).

Deviating slopes (and intercepts) of $\mathrm{Cd} /$ shell-wt regressions indicate recent trends: When the small individuals have grown under conditions of altered (e.g. increased) environmental cadmium, the slope will fall below and the intercept will e x c e e d normal values, and vice versa. The $\mathrm{Cd} /$ shellwt ratio derived from small specimens reflects the environmental $\mathrm{Cd}$ in a short period before sampling; older mussels give an integrated picture corresponding to their longer life span (Fig. $7 \mathrm{c}$ ).

\section{Cd/shell-wt index}

Since the slope $b$ of the $\mathrm{Cd} /$ shell-wt regression

$$
\log \mathrm{Cd}=\log a+b \log \text { shell wt }
$$

has been shown to vary to a minor extent only, biologi- cal monitoring of $\mathrm{Cd}$ can be based on the intercept log $a$, using mussels of the same shell weight. Referring to a standard shell weight of $1 \mathrm{~g}$ would give

$$
\log \mathrm{Cd}=\log \mathrm{a}
$$

Transformation to linear scales produces

$$
\mathrm{Cd}=\mathrm{a}
$$

$a$ is termed the

$\mathrm{Cd} /$ shell-wt index.

It is the amount of $\mathrm{Cd}(\mu \mathrm{g})$ in the soft body of a mussel having a shell weight of $1 \mathrm{~g}$. The $\mathrm{Cd} /$ shell-wt index is derived from a $\log \mathrm{Cd} / \log$ shell wt regression with a slope $b$ different from 1 and should not be misconceived as a mere ratio. $\mathrm{Cd} / \mathrm{shell}$-wt indices and, to a lesser extent, the slopes of the respective regression lines are distinct for different species of conchifers (Table 1)

\section{Outlines for sampling design}

Naturally, when using shell weight as an independent variable, mussels with eroded shells should not be collected. Comparisons should refer to mussels from the same salinity, since the chemical speciation (Mantoura et al., 1978) and the concentrations of $\mathrm{Cd}$ and $\mathrm{Ca}$ relative to each other are modified by this environmental variable.

No sampling restrictions as to individual size, position in the water column, or season need to be observed. Sampling instructions of conventional ('Mussel Watch') programmes (reference of metal content to soft-body weight) can be accomplished by recording individual shell weight as an additional parameter.

Analyses of numerous individuals covering a size range as wide as possible provide information as to the present state and the trend of environmental cadmium. The (logged) Cd/shell-wt regressions must be calculated.

Alternatively analyses of several, say 10 to 15 , individuals of the same size can be performed. Individual $\mathrm{Cd} /$ shell-wt ratios must be normalised to the standard shell weight of $1 \mathrm{~g}$ to produce the $\mathrm{Cd} / \mathrm{shell}$-wt index (log-transformation and normalisation with the slope $b$; Table 4). Means and standard deviations are then calculated. Results from large individuals reflect mean environmental $\mathrm{Cd}$ over an extended life span; results from small individuals reflect the state during a shorter period before sampling. Samples can be pooled when individuals have the same shell weight. Normalisation can be avoided by choosing specimens of $1 \mathrm{~g}$ shell weight from the outset. The shell length of such 'standard' individuals was approximately 28 to $31 \mathrm{~mm}$ in submerged mussels from both Western Baltic Sea and 
German Wadden Sea. Relating soft-body weight to shell weight may provide additional information on health and growth conditions of mussels.

$\mathrm{Cd} /$ shell-wt index and environmental $\mathrm{Cd}$

\section{Kiel Bight background}

Water data are reported by Kremling et al. (1979): no significant local and seasonal changes of dissolved cadmium were observed from Jan. 1977 to June 1978 at a number of sampling stations from the inner Eckernförde Bight to the open Kiel Bight. The mean $\mathrm{Cd}$ concentration was $71 \mathrm{ng} \mathrm{\textrm {dm } ^ { - 3 }}(\mathrm{SD}=40 ; \mathrm{n}=27)$.

Mussel data refer to 5 analyses of the $\mathrm{Cd} / \mathrm{shell}-\mathrm{wt}$ regressions from autumn 1980 to spring 1981 with a mean sample size of 64 individuals; sampling was done at Locations 2 to 4 (Fig. 1). The $95 \%$ confidence interval of the $\mathrm{Cd} / \mathrm{shell}-\mathrm{wt}$ indices was $.2291<.2434<.2596$.

\section{(2) Pollution gradient in Kiel Harbour}

Water data on dissolved Cd (Jan. 1977 to June 1978; Kremling et al., 1979) reveal an overall decline of $\mathrm{Cd}$ concentration in Kiel Harbour (off Location 9) towards the inner Kiel Fjord (off Location 7), where Kiel Bight levels are reached. The same trend has been observed in the Cd/shell-wt indices of Mytilus edulis from Location 10 northward (sampling: winter 1980/81).

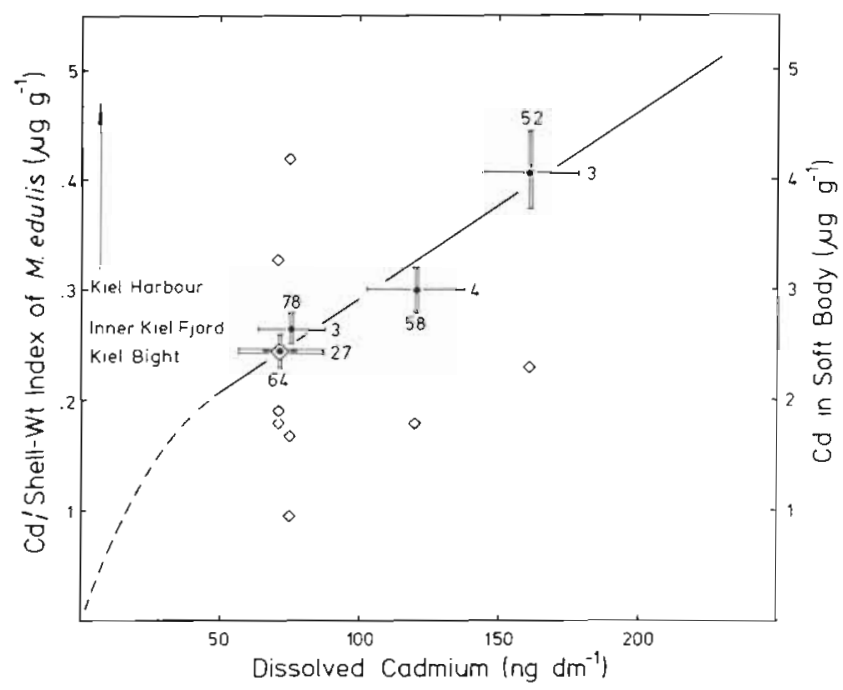

Fig. 8. Mytilus edulis from Kiel Fjord and Western Baltic Sea. Possible relationship between $\mathrm{Cd} /$ shell-wt index (winter 1980/81; this study) and dissolved Cd (1977-1978; Kremling et al. 1978). Double bars: $95 \%$ confidence intervals of mean values; single bars: SD of mean values; diamonds: mean $\mathrm{Cd}$ concentration in soft parts (this study)
The 2 sets of data are combined on the assumption that no major changes of environmental Cd with time have occurred under normal meteorological and hydrographical conditions from 1978 to 1980 (Fig. 8). The $\mathrm{Cd}$ concentration (diamonds) is given for comparison.

\section{(3) Evaluation}

Earlier data on $\mathrm{Cd}$ concentrations of mussels from Kiel Fjord and Eckernförde Bight (Theede et al., 1979; sampling: winter $1975 / 76$ ) confirm the assumption that there have been no major changes in the environmental Cd background through the years. The 1975/76 concentrations in mussels from Kiel Harbour, however, were considerably higher. Thus the general trend of $\mathrm{Cd}$ from higher values in Kiel Harbour towards lower values in the inner Kiel Fjord is well documented, but not the extent of this decline, i.e. the slope of the interrelationship. Because of this uncertainty, the information in Fig. 8 is tentative without calculating the regression. The principle advantage of basing the biological monitoring of environmental $\mathrm{Cd}$ on the $\mathrm{Cd}$ / shell-wt index, however, becomes evident by an unequivocal positive interrelationship. This cannot be said with regard to $\mathrm{Cd}$ concentrations

\section{DISCUSSION}

\section{Immobilisation of $\mathrm{Cd}$ and $\mathrm{Ca}$}

Close interrelations between $\mathrm{Cd}$ in the soft tissues of mussels and the weight of their shells have been found throughout this study, the $\mathrm{Cd}$ concentration changing inversely with respect to condition index, for various reasons. Accumulation of $\mathrm{Cd}$ and depositing of $\mathrm{Ca}$ as carbonate in the shell take place at constant rates relative to each other. Irrespective of metabolic turnover, both processes can be regarded as organismic net immobilisation of matter which produces increasing amounts with time. It seems attractive to compare pathways and balance of $\mathrm{Cd}$ and $\mathrm{Ca}$, the more so since both elements occur as free bivalant ions in the marine environment (Mantoura et al., 1978) and have a similar ion radius.

With regard to $\mathrm{Ca}$, scientific consensus states that the main route into molluscs is influx from the water, and that immobilisation in the shells is virtually irreversible (reviews: Allen, 1963; Wilbur, 1964, 1972)

Concerning the path w y s of $\mathrm{Cd}$ (and other toxic metals) there are differences of opinion. Incorporation by molluscs under environmental conditions has been discussed prevalently in relation to filter feeding on suspended food (reviews: Phillips, 1977; Wright, 1978), 
or ingesting other particles, such as mud (e.g. Talbot et al., 1976; Bryan and Uysal, 1978), that may contain increased levels of metals. Storage of metals in the digestive gland was interpreted as indicating uptake via the digestive tract (e.g. Bryan and Hummerstone, 1978; Bryan and Uysal, 1978). In contrast, passive influx from water is implied to be more important in most experimental work on toxic effects or on exchange rates - the so-called dynamics -, since high doses of metals are administered as inorganic salts and the animals are not fed (reviews: Wright, 1978; Møhlenberg and Jensen, 1980).

Concrete results on uptake routes of $\mathrm{Cd}$ under equilibrated conditions are scarce. According to Kerfoot and Jacobs (1976), oysters accumulated $90 \%$ directly from the water and $10 \%$ from food when grown under conditions of slightly elevated environmental Cd and fed equilibrated food. This study presents a confirmation from field investigations for the predominance of the direct route from water into molluscs, as with $\mathrm{Ca}$ : mussels of low condition, that have been cut off from nutrient supply by directly adjacent well-fed competitors, exhibited the same $\mathrm{Cd} /$ shell-wt ratio. Investigations on other metals indicate that influx from water may be more important in general (Dahlgaard, 1981; Miramand et al., 1982) with the possible exception of predatory gastropods (review: Mohlenberg and Jensen, 1980).

Once accumulated from the marine environment, depuration of $\mathrm{Cd}$ from molluscs is of minor importance (Peden et al., 1973; Phillips, 1976a; Bryan and Hummerstone, 1978; Greig and Wenzloff, 1978; Noël-Lambot et al., 1980). The fact that highest body burdens are correlated with highest shell weights in senescent mussels (this study) confirms that cumulative net uptake under field conditions is a similar irreversible process.

Losses during spawning have been reported for contaminated oysters (Zaroogian, 1980). In mussels, however, Cd balance is not affected to a detectable extent by spawning (this study). Concentration-dependent influx/efflux rates have been observed in short-term laboratory experiments (e.g. Scholz, 1980), where the high doses applied most certainly exceeded the organismic capacity to bind $\mathrm{Cd}$. Fowler and Benayoun (1974) calculated biological half-lives of up to $3.4 \mathrm{yr}$ after mussels had lost exchangeable fractions of low radiocadmium doses. This calls for some caution when interpreting results of short-term experiments and underlines the capacity of mussels to integrate m e a n levels of environmental $\mathrm{Cd}$. This study has shown that an average long-term state of environmental $\mathrm{Cd}$ is reflected in the $\mathrm{Cd} / \mathrm{shell}-\mathrm{wt}$ index of large mussels. Small individuals reflect the recent environmental level according to their shorter life span (Fig. $7 \mathrm{c}$ ).

\section{Immobilised organic ligands}

Either process, the accumulation of $\mathrm{Cd}$ in the soft body as well as the formation of the calcareous shell, includes net transfer of specific organic ligands from the living pool of the soft body to metabolically inert metallo-organic compounds or to the stable structure of shells.

The free $\mathrm{Cd}^{++}$ion has a strong affinity for functional groups and especially for the sulfhydryl group. Acute toxicity of high doses is a result of this property, $\mathrm{Cd}$ replacing essential metals and occupying their specific binding sites (review: Vallee and Ulmer, 1972). Longterm toxicity of low doses, Cd cumulatively loading certain organs (like kidney in man; review: Friberg et al., 1974) is a consequence of the same biochemical property, and of a low organismic capacity to excrete $\mathrm{Cd}$. Immobilised $\mathrm{Cd}$ is bound to thioneins - proteins with a characteristically high percentage of the sulfur amino acid cysteine (Kägi and Vallee, 1960; review: Kägi and Nordberg, 1979). Thioneins have been found in many systematic categories, from protozoans (e.g. Al-Atia, 1980) to vertebrates where they were detected first (Margoshes and Vallee, 1957). A significant biological function has not been detected so far (Vallee, 1979). In molluscs, detectable quantities may be present under environmental conditions (e.g. Howard and Nickless, 1977), and positive interrelations between $\mathrm{Cd}$, metallothionein, and individual age have been found in limpets (Noël-Lambot et al., 1980). In mussels, thioneins or similar protein fractions have been recorded after laboratory contamination with high doses of $\mathrm{Cd}$ in the water (Noël-Lambot, 1976; George et al., 1979; Scholz, 1980; Köhler and Riisgård, 1982).

Molluscan shells are covered by the organic periostracum, and the calcium carbonate crystals are inbedded in an organic matrix (reviews: Wilbur, 1964, 1972). Main organic structural elements of Mytilus edulis shells are the amino acids glycine (291), alanine (216), aspartate (118) and serine (98 of 1000 residues; review: Wilbur and Simkiss, 1968). Though they have only a ca. $5 \%$ share of the shell dry weight of Western Baltic mussels (Schlieper and Kowalski, 1957), the amount of the organic components of shells should not be underestimated: basing balance calculations on a mean shell-weight/dry-weight ratio of 6.5 in Western Baltic mussels (this study, Fig. 7a), periostracum and organic matrix equal $30 \%$ in relation to the weight of the soft tissues. There must be a considerable potential in the soft bodies' metabolism for providing proteinaceous organic substances to be transferred to the shells. 


\section{Metabolic interactions?}

The main amino acid constituents of mussel shells (Gly, Ala, Asp, and Ser) also represent a major proportion of the intracellular pool of free amino acids (FAA) - in Mytilus edulis ca. 50 \% (adductor muscle; Gilles, 1972). Gly, Ala, and Ser are main constituents of (vertebrate) metallothioneins as well (Kägi and Nordberg, 1979). The molar concentration of the intracellular FAA pool follows salinity changes, and a characteristic osmotically active substance in many molluscs, including $M$. edulis, is the amine taurine (Lange, 1963; Bricteux-Grégoire et al., 1964; Gilles, 1972; review: Gilles, 1975). It has been confirmed for blue mussels that Cys, the characteristic element of the thioneins, is the metabolic precursor of taurine (Allen and Awapara, 1960). Cys itself is derived from Ser. Chemical speciation of environmental $\mathrm{Cd}$ and Ca (Mantoura et al., 1978) and concentrations relative to each other are determined by salinity.

Combination of the above findings (Fig. 9) implies functional interrelations between $\mathrm{Cd}$ accumulation in soft tissues and Ca deposition in shells, the osmotic reactivity and the synthesis potential of the molluscan intracellular FAA pool playing a central role in both immobilisation processes. It may be of importance to note a dominant role of taurine in some intertidal molluscs such as Littorina littorea, Patella vulgata and Nucella lapillus (Hoyeaux et al., 1976), and high $\mathrm{Cd}$ concentrations in the same species (Butterworth et al., 1972; this study). Vice versa, minor amounts of taurine

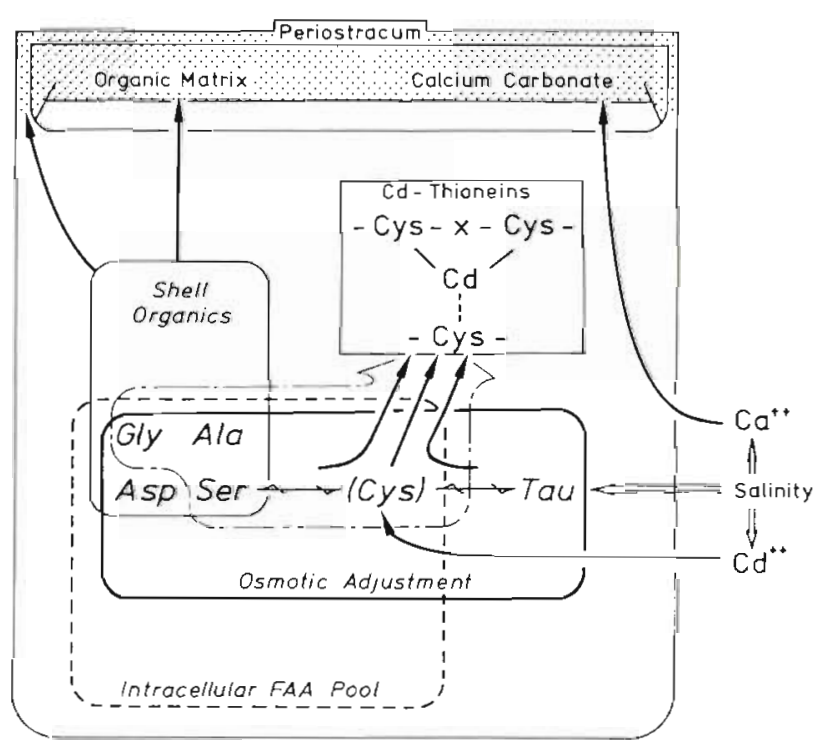

Fig. 9. Model of interrelationship between shell formation and $\mathrm{Cd}$ accumulation in marine molluscs. (Living structures rounded, immobilised structures angular). Are shell formation and $\mathrm{Cd}$ accumulation linked by multiple functions of sulfur amino acids in the physiology of mol.luscs? were found in Mya arenaria (DuPaul and Webb, 1970). This species exhibits considerably lower cadmium concentrations (this study)

\section{Current problems of biological monitoring}

Relating heavy-metal content of soft tissues to weight of soft tissues has been accepted for expressing analytical results of 'Mussel Watch' programmes. However, the great variability of soft-body weight has been recognized as a limitation of the conventional approach. Sampling instructions (Phillips, 1976a; Cossa et al., 1979; Orren et al., 1980) are attempts to reduce variability of metal concentrations by eliminating the variability of the soft body weight.

This study has shown that the cadmium concentration of the soft body reflects, above all, the nutritional state of mussels, unless differences of environmental Cd exceed the variability of the condition index.

The idea of relating accumulated heavy-metal content with a less variable parameter, e.g. with the protein fraction of the soft body, was touched on by Zaroogian (1980). Simkiss and Taylor (1981) suggest expressing analytical results as ratios of pollutants to essential elements until future knowledge of specific metabolic pathways allows the essential elements to be related to their interfering toxicants.

\section{Alternative approach}

This study introduces shell weight as an alternative parameter in relation to the amount of heavy metals in the soft body of molluscs, investigating, as an example, the interrelationship with $\mathrm{Cd}$ in detail. The basic concept has been to regard accumulation as the consequence of organismic immobilisation. Body burdens thus increase with time, and they should be related with time (individual age) itself or with parameters of a similar cumulative character - such as the weight of calcereous shells. Age determination of mussels was recognized as a key problem of monitoring metals with long biological half-lives (Goldberg et al., 1978). Attempts to describe the age of mussels by means of metal concentrations and shell thickness (Griffin et al., 1980) introduced an additional, highly variable parameter. Concerning $\mathrm{Cd}$, using shell weight as an independent variable has been shown to be a feasible way out of the current difficulties.

However, all parameters that alter the rates of $\mathrm{Cd}$ accumulation and shell formation relative to each other, must be allowed for. With regard to relative rates, temperature may be of minor importance because both biochemical processes take place at the 
same temperature. Salinity as the second major environmental variable in coastal areas may alter the $\mathrm{Cd} /$ shell-wt index by influencing physiologically determined rates of both processes, and by modifying the availability of $\mathrm{Cd}$ and $\mathrm{Ca}$ to different extents. Research on this aspect is only beginning, and for the time being comparisons should be restricted to results concerning the same salinity.

The new approach to biological monitoring requires a record of the shell weight of mussels as an additional parameter. This can be achieved precisely with no great additional expense. Applying the $\mathrm{Cd} /$ shell-wt index for monitoring environmental $\mathrm{Cd}$, relating soft body weight to shell weight as well can produce additional information, e.g. on health and growth conditions. Conventional concentration values of commercial shellfish will remain important concerning public health.

Would shell weight be an adequate parameter in relation to other heavy metals as well? This can be predicted for metals (and other toxicants) that accumulate in the soft body of molluscs due to biochemical immobilisation processes. As a consequence, such metals would have a long biological half-life. Storage in the digestive gland may indicate relative constancy of metal body burden since weight fluctuations concern mainly gonads and connective tissues. Further research should provide definite results, and some findings suggest this may be a promising approach: The concentrations of mercury (DeWolf, 1975) and lead (Griffin et al., 1980) in the soft body of mussels have been reported to be positively related with tidal exposure $(\mathrm{Hg})$ or shell thickness $(\mathrm{Pb})$. Lobel and Wright (1982) found an inverse relationship between $\mathrm{Zn}$ concentration and meat condition (in terms of meat/shell) in mussels from different shore levels. Hence, shell weight might be an appropriate independent variable also in relation to other (but probably not all) metals.

Documentation is required for each metal, and research on $\mathrm{Cd}$ is to be continued. I feel encouraged, however, to recommend basing the monitoring of environmental $\mathrm{Cd}$ on the $\mathrm{Cd} /$ shell-wt index, and I suggest recording shell weight as an additional routine parameter of 'Mussel Watch' programmes in general.

Acknowledgements. This study is based on author's Dr. rer. nat. thesis. Thanks are due to Professor Dr. H. Theede for stimulating discussions. The author gratefully acknowledges being given the opportunity to initiate a research programme of his own. Financial support: Umweltbundesamt ref. no. 10607033 to $\mathrm{H}$. Theede.

\section{LITERATURE CITED}

Al-Atia, G. R. (1980). Toxicity of cadmium to Amoeba proteus: A biochemical approach. J. Protozool, 27: 128-132
Allen, A. S. (1963). Ecology and functional morphology of molluscs. Oceanogr. mar. Biol. A. Rev. 1: 253-288

Allen, K., Awapara, J. (1960). Metabolism of sulfur amino acids in Mytilus edulis and Rangia cuneata. Biol. Bull. mar. biol. Lab., Woods Hole 118: 173-181

Baird, R. H., Drinnan, R. E. (1957). The ratio of shell to meat in Mytilus as a function of tidal exposure. J. Cons. int. Explor. Mer 22: 329-336

Bayne, B. L., Worrall, C. M. (1980). Growth and production of mussels Mytilus edulis from two populations. Mar. Ecol. Prog. Ser. 3: 317-328

Boyden, C. R. (1974). Trace element content and body size in molluscs. Nature, Lond. 251: 311-314

Boyden, C. R. (1977). Effect of size upon metal content of shellfish. J. mar. biol. Ass. U. K. 57; 675-714

Bricteux-Grégoire, S., Duchâteau-Bosson, G., Jeuniaux, C., Florkin, M. (1964). Constituants osmotiquement actifs des muscles adducteurs de Mytilus edulis adaptée à l'eau de mer ou à l'eau saumâtre. Arch. int. Physiol. Biochem. 72: $116-123$

Bryan, G. W., Hummerstone, L. G. (1978). Heavy metals in the burrowing bivalve Scrobicularia plana from contaminated and uncontaminated estuaries. J. mar. biol. Ass. U. K. 58 : $401-420$

Bryan, G. W., Uysal, H. (1978). Heavy metals in the burrowing bivalve Scrobicularia plana from the Tamar Estuary in relation to environmental levels. J. mar. biol. Ass, U. K. 58: 89-108

Butterworth, J., Lester, P., Nickless, G. (1972). Distribution of heavy metals in the Seven Estuary. Mar. Pollut. Bull. 3: $72-74$

Cossa, D., Bourget, E., Piuze, J. (1979). Sexual maturation as a source of variation in the relationship between cadmium concentration and body weight of Mytilus edulis L. Mar. Pollut. Bull. 10: 174-176

Dahlgaard, H. (1981). Bioindicators for monitoring radioactive pollution of the marine environment. Risø National Lab. Roskilde, Repro 443

Darracott, A., Watling, H. (1975). The use of molluscs to monitor cadmium levels in estuaries and coastal marine environments. Trans. R. Soc. S. Afr. 41: 325-338

Davies, I. M., Pirie, J. M. (1980). Evaluation of a Mussel Watch' project for heavy metals in Scottish coastal waters. Mar. Biol. 57: 87-93

DeWolf, P. (1975). Mercury content of mussels from West European coasts. Mar. Pollut. Bull. 6: 61-63

DuPaul, W. D., Webb, K. L. (1970). The effect of temperature on salinity-induced changes in the free amino acid pool of Mya arenaria. Comp. Biochem. Physiol. 32: 785-801

Ehrhardt, M., Wenk, A. (1982). Wind pattern and hydrogen sulfide in shallow waters of the Western Baltic Sea, a cause and effect relationship? Report for the 13th CBO, Helsinki 24-27 Aug. 1982; to be published in Ber. dt. wiss. Kommn. Meeresforsch.

Fowler, S. W., Benayoun, G. (1974). Experimental studies on cadmium flux through marine biota. In: International Atomic Energy Agency (ed.) Comparative studies of food and environmental contamination. Proc. Sympos., Wien, p. $159-178$

Friberg, L., Piscator, M., Nordberg, G. F., Kjellström, T. (1974). Cadmium in the environment. CRC Press, Cleveland Ohio

Gabbott, P. A., Walker, A. J. M. (1971). Changes in the condition index and biochemical content of adult oysters (Ostrea edulis L.) maintained under hatchery conditions. J. Cons. int. Explor. Mer 34: 99-106

George, S. G., Carpene, E., Coombs, T. L., Overnell, J., 
Youngson, A. (1979). Characterisation of cadmium-binding proteins from mussels, Mytilus edulis (L.), exposed to cadmium. Biochim. biophys. Acta 580: 225-233

Gilles, R. (1972). Osmoregulation in three molluscs: Acanthochitona discrepans (Brown), Glycymeris glycymeris (L.) and Mytilus edulis (L.). Biol. Bull. mar. biol. Lab. Woods Hole 142: 25-35

Gilles, R. (1975). Mechanisms of ion and osmoregulation. In: Kinne, O. (ed.) Marine ecology, Vol. II, Physiological mechanisms. Wiley, New York, p. 259-347

Goldberg, E. D. (1975). The mussel watch - a first step in global marine monitoring. Mar. Pollut. Bull. 6: 111

Goldberg, E. D., Bowen, V T., Farrington, J. W., Harvey, G., Martin, J. H., Parker, P. L., Risebrough, R. W., Robertson, W., Schneider, E., Gamble, E. (1978). The mussel watch. Environ. Conserv. 5: 101-125

Greig, R. A., Wenzloff, D. R. (1978). Metal accumulation and depuration by the American oyster Crassostrea virginica. Bull, environ. Contam. Toxicol. 20: 499-504

Griffin, J. J., Koide, M., Hodge, V., Goldberg, E. D. (1980). Estimating the ages of mussels by chemical and physical methods. In: Goldberg, E. D., Horibe, Y., Saruhashi, K. (eds.) Isotope marine chemistry. Rokakuho, Tokyo, p. 193-209

Havinga, B. (1929). Krebse und Weichtiere. In: Lübbert, H., Ehrenbaum, E. (eds.) Handbuch der Seefischerei Nordeuropas, Vol. III (2). Schweizerbart, Stuttgart, p. 1-147

Howard, A. G., Nickless, G. (1977). Heavy metal complexation in polluted molluscs. I. Limpets (Patella vulgata and Patella intermedia). Chem.-Biol. Interact. 16: 107-114

Hoyaux, J., Gilles, R., Jeuniaux, Ch. (1976). Osmoregulation in molluscs of the intertidal zone. Comp. Biochem. Physiol. 53A: 361-365

Jensen, K., Randløv, A., Riisgård, H. U. (1981). Heavy metal pollution from a point source demonstrated by means of mussels, Mytilus edulis. Chemosphere 10: 761-765

Jörgensen, C. B. (1976). Growth efficiencies and factors controlling size in some mytilid bivalves, especially Mytilus edulis: a review and interpretation. Ophelia 15: 175-192

Kägi, J. H. R., Nordberg, M. (eds.) (1979). Metallothionein. Birkhäuser, Basel

Kägi, J. H. R., Vallee, B. L. (1960), Metallothionein: a cadmium and zinc-containing protein from equine renal cortex. J. biol. Chem. 235: 3460-3465

Kändler, R. (1960). Typen der Salzgehalts- und Temperaturschichtung in der Kieler Förde. Kieler Meeresforsch. 16: 164-179

Kerfoot, W. B., Jacobs, S. A. (1976). Cadmium accrural in combined wastewater treatment - aquaculture system. Environ. Sci. Technol. 10: 662-667

Köhler, K., Risgård, H. U. (1982). Formation of metallothioeins in relation to accumulation of cadmium in the common mussel Mytilus edulis. Mar. Biol. 66: 53-58

Kremling, K. (1982). The behavior of $\mathrm{Zn}, \mathrm{Cd}, \mathrm{Cu}, \mathrm{Ni}, \mathrm{Co}, \mathrm{Fe}$, and $\mathrm{Mn}$ in anoxic Baltic waters. Mar. Chem. (submitted)

Kremling, K., Otto, C., Petersen, H. (1979). SpurenmetallUntersuchungen in den Förden der Kieler Bucht. Ber. Inst. Meeresk. Univ. Kiel 66: 1-38

Lange, R. (1963). The osmotic function of amino acids and taurine in the mussel Mytilus edulis. Comp. Biochem. Physiol. 10: 173-179

Lenz, J. (1981). Phytoplankton standing stock and primary production in the Western Baltic. Kieler Meeresforsch. Sonderh. 5: 29-40

Lobel, P. B., Wright, D. A. (1982). Total body zinc concentration and allometric growth ratios in Mytilus edulis collected from different shore levels. Mar Biol. 66: 231-236
Loosanoff, V. L., Davis, H. C. (1963). Rearing of bivalve mollusks. Adv. mar. Biol. 1. 1-136

Mantoura, R. F. C., Dickson, A., Riley, J. P. (1978). The complexation of metals with humic materials in natural waters. Estuar. coast. mar. Sci. 6: 387-408

Margoshes, M., Vallee, B. L. (1957). A cadmium protein from equine kidney cortex. J. Am. Chem. Soc. 79: 4813

Miramand, P., Germain, P., Camus, H. (1982). Uptake of americum and plutonium from contaminated sediments by three benthic species: Arenicola marina, Corophium volutator and Scrobicularia plana. Mar. Ecol. Prog. Ser. 7 : 59-65

Møhlenberg, F., Jensen, A. (1980). The ecotoxicology of cadmium in fresh and sea water and water pollution with cadmium in Denmark. National Agency of Environmental Protection, Charlottenlund

Noël-Lambot, F. (1976). Distribution of cadmium, zinc and copper in the mussel Mytilus edulis. Existing of cadmiumbinding proteins similar to metallothioneins. Experienta 32: $324-326$

Noël-Lambot, F., Bouquegneau, J. M., Frankenne, F., Disteche, A. (1980). Cadmium, zinc and copper accumulation in limpets (Patella vulgata) from the Bristol Channel with special reference to metallothioneins. Mar. Ecol. Prog. Ser. 2: 81-89

Orren, M. J., Eagle, G. A., Hennig, H. F.-K. O., Green, A. (1980). Variation in trace metal content of the mussel Choromytilus meridionalis (Kr.) with season and sex. Mar. Pollut. Bull. 11: 253-257

Peden, J. D., Crothers, J. H., Waterfall, C. E., Beasley, J. (1973). Heavy metals in Somerset marine organisms. Mar. Pollut. Bull. 4: 7-9

Phillips, D. J. H. (1976a). The common mussel Mytilus edulis as an indicator of pollution by zinc, cadmium and copper. I. Effects of environmental variables on uptake of metals. Mar. Biol. 38: 59-69

Phillips, D. J. H. (1976b). The common mussel Mytilus edulis as an indicator of pollution by zinc, cadmium, lead and copper. II. Relationship of metals in the mussel to those discharged by industry. Mar. Biol. 38: 71-80

Phillips, D. J. H. (1977). The use of biological indicator organisms to monitor trace metal pollution in marine and estuarine environments - a review. Environ. Pollut. 13: 281-317

Phillips, D. J. H. (1980). Quantitative aquatic biological indicators. Applied Science Publishers Ltd, London

Popham, J. D., Johnson, D. C., D'Auria, J. M. (1980). Mussels (Mytilus edulis) as 'point source' indicators of trace metal pollution. Mar. Pollut. Bull. 11: 261-263

Probst, B. (1977). Primary production. In: Rheinheimer, G (ed.) Microbial ecology of a brackish water environment Springer, Berlin, p. 71-78

Sachs, L. (1978). Angewandte Statistik. Springer, Berlin

Schlieper, C., Kowalski, R. (1957). Weitere Untersuchungen zur ökologischen Physiologie der Miesmuschel Mytilus edulis L.. Kieler Meeresforsch. 13: 3-10

Scholz, N. (1980). Accumulation, loss and molecular distribution of cadmium in Mytilus edulis. Helgoländer Meeresunters. 33: 68-78

Schulz-Baldes, M. (1973). Die Miesmuschel Mytilus edulis als Indikator für die Bleikonzentration im Weserästuar und in der Deutschen Bucht. Mar. Biol. 21: 98-102

Seed, R. (1968). Factors influencing shell shape in Mytilus edulis L. J. mar biol. Ass. U. K. 48: 561-584

Simkiss, K., Taylor, M. (1981). Cellular mechanisms of metal ion detoxification and some new indices of pollution. Aquat. Toxicol. 1: 279-290 
Sperling, K.-R. (1982). Cadmiumbestimmungen in Küstenwasserproben aus der Deutschen Bucht. Vom Wasser 58: $113-142$

Sturesson, U. (1978). Cadmium enrichment in shells of Mytilus edulis. Ambio 7: 122-125

Talbot, V. W., Magee, R. J., Hussain, M. (1976). Cadmium in Port Phillip Bay mussels. Mar. Pollut. Bull. 5: 84-86

Theede, H., Andersson, I., Lehnberg, W. (1979). Cadmium in Mytilus edulis from German coastal waters. Meeresforsch. $27: 147-155$

Umweltbundesamt (ed.) (1981). Cadmium-Bericht. Umweltbundesamt, Berlin

Vallee, B. L. (1979). Metallothionein: Historical review and perspectives. In: Kägi, J. H. R., Nordberg, M. (eds.) Metallothionein. Birkhäuser, Basel, p. 19-40
Vallee, B. L., Ulmer, D. D. (1972). Biochemical effects of mercury, cadmium and lead. A. Rev. Biochem. 41: 91-128

Wilbur, K. M. (1964). Shell formation and regeneration. In: Wilbur, K. M., Yonge, C. M. (eds.) Physiology of mollusca I. Academic Press, New York, p. 243-282

Wilbur, K. M. (1972). Shell formation in mollusks. In: Florkin, M., Scheer, B. T (eds.) Chemical zoology VII, Mollusca. Academic Press, New York, p. 103-145

Wilbur, K. M., Simkiss, K. (1968). Calcified shells. Comp. Biochem. 26A: 229-295

Wright, D. A. (1978). Heavy metal accumulation by aquatic invertebrates. Appl. Biol. 3: 331-381

Zaroogian, G. E. (1980). Crassostrea virginica as an indicator of cadmium pollution. Mar. Biol. 58: 275-284

This paper was submitted to the editor; it was accepted for publication on January 12, 1983 